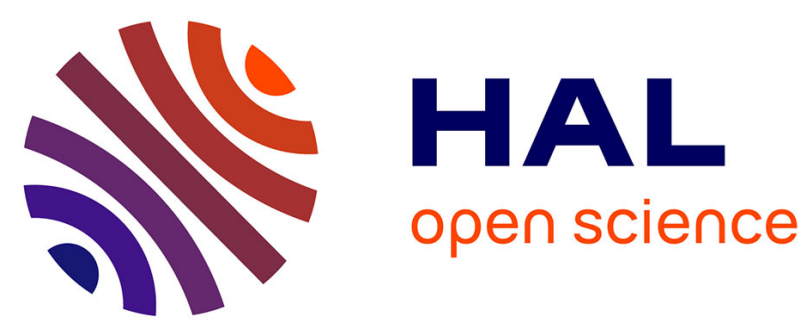

\title{
(2R)- and (2S)- 2-hydroxy Hexanoyl and Octanoyl-l-Homoserine Lactones: new highly potent Quorum Sensing modulators with opposite activities
}

\author{
Qiang Zhang, Erwann Jeanneau, Yves Queneau, Laurent Soulère
}

\section{- To cite this version:}

Qiang Zhang, Erwann Jeanneau, Yves Queneau, Laurent Soulère. (2R)- and (2S)- 2-hydroxy Hexanoyl and Octanoyl-l-Homoserine Lactones: new highly potent Quorum Sensing modulators with opposite activities. Bioorganic Chemistry, 2020, pp.104307. 10.1016/j.bioorg.2020.104307 . hal-02952061

\section{HAL Id: hal-02952061 \\ https://hal.science/hal-02952061}

Submitted on 29 Sep 2020

HAL is a multi-disciplinary open access archive for the deposit and dissemination of scientific research documents, whether they are published or not. The documents may come from teaching and research institutions in France or abroad, or from public or private research centers.
L'archive ouverte pluridisciplinaire HAL, est destinée au dépôt et à la diffusion de documents scientifiques de niveau recherche, publiés ou non, émanant des établissements d'enseignement et de recherche français ou étrangers, des laboratoires publics ou privés. 


\title{
(2R)- and (2S)- 2-hydroxy Hexanoyl and Octanoyl-L-Homoserine Lactones: new highly potent Quorum Sensing modulators with opposite activities
}

\author{
Qiang Zhang, ${ }^{\mathrm{a}}$ Erwann Jeanneau, ${ }^{\mathrm{b}}$ Yves Queneau ${ }^{\mathrm{a} *}$ and Laurent Soulère ${ }^{\mathrm{a} *}$
}

${ }^{a}$ Univ Lyon, Université Claude Bernard Lyon 1, INSA Lyon, CPE Lyon, UMR 5246, CNRS, ICBMS, Institut de Chimie et de Biochimie Moléculaires et Supramoléculaires, Chimie Organique et Bioorganique, Bât. E. Lederer, 1 rue Victor Grignard F-69622 Villeurbanne, France.

${ }^{\mathrm{b}}$ Univ Lyon, Université Claude Bernard Lyon 1, Centre de Diffractométrie Henri Longchambon, 5 rue de La Doua, 69100 Villeurbanne, France

* Corresponding authors at: ICBMS, Chimie Organique et Bioorganique, Bât. E. Lederer, 1 rue Victor Grignard F-69622 Villeurbanne, France.

E-mail addresses: yves.queneau@insa-lyon.fr and laurent.soulere@insa-lyon.fr 
Abstract - The synthesis and the QS modulation activity of diastereoisomerically pure 2hydroxy acyl-L-homoserine lactones (2-OH-AHLs) are unveiled. (2R)- and (2S)- 2-Hydroxy hexanoyl-L-homoserine lactone and 2-hydroxy octanoyl-L-homoserine lactone have been identified as very potent QS agonists and antagonists on the Vibrio fischeri-quorum sensing system with opposite activities depending on the configuration of the carbon atom with the hydroxyl group. Flexible molecular docking showed that the $(2 R)-\mathrm{OH}$ configuration in the antagonist isomer induces new hydrogen bonds with Tyr70 and Asp79, two importantly conserved residues in the LuxR protein family, while the (2S)-OH agonist configuration exhibits a binding mode comparable to the natural ligand 3-oxo-hexanoyl-L-homoserine lactone (OHHL). For the analogs with long alkyl chain $\mathbf{3 a}$ and $\mathbf{3 b}$ and aromatic analogs, all are antagonists with no effect of the configuration at C-2.

Keywords - Quorum sensing, 2-Hydroxy AHL, Flexible docking 


\section{Introduction}

Quorum sensing (QS) is a bacterial system of communication [1] allowing bacteria to communicate with each other and synchronize their behavior according to their population density, notably by regulating the expression of genes including those responsible for the virulence. The modulation of QS opens therefore new perspectives to decrease bacterial virulence in biotechnologies as well as in medicine [2-6].

The QS process is based on small diffusible molecules called autoinducers capable of binding to specific protein receptors, which are transcription factors allowing the regulation of target genes encoding for particular phenotypes. An important approach to interfere with QS is the development of molecules able to bind the same receptors [7-9]. In terms of chemical structure, several types of autoinducers are found, such as acyl homoserine lactones (AHLs) (AI-1) in Gram negative bacteria [10], such as for example the pathogenic Pseudomonas aeruginosa, cyclic peptides in Gram positive bacteria such as Staphylococcus aureus [11], or dihydroxypentanedione (DPD, AI-2) in both Gram positive and Gram negative bacteria [12]. With respect to AHL, their structure differs according to bacterial strains and their general structure is depicted in Figure 1. Structural variations such as the modifications of the amide functional group with bioisosteres, or modification of the lactone part or of the side-chain have been shown to lead to different biological responses [7-9]. A structural feature of AHLs is the the possible presence of a 3-oxo functional group (for Vibrio fischeri or Pseudomonas aeruginosa) or of a (3R)-hydroxyl functional group (for Vibrio harveyi) [13] on the acyl chain. It has been shown that the oxo group interfere within the binding site of the some receptors in the LuxR protein family by bridging one water molecule [14]. 2-Oxo analogs have been reported twice and found inactive $[15,16]$. 
In the pathogen Acinetobacter baumannii, among (3R) and (3S) hydroxyl C12 homoserine-Llactone diastereoisomers, both have been found to exert agonistic activities, the $(3 R)$ isomer being the most active and probably the natural autoinducer [17]. If a few studies discuss the biological properties of analogs of 3-oxo and 3-hydroxy derivatives [15, 17], no systematic study of enantiomerically pure 2-hydroxy AHL analogs has ever been reported. Only a mixture of four possible isomers of 2-hydroxybutanoyl homoserine lactone was tested and found inactive on Vibrio harveyi QS [18]. In the context of our work on QS chemical modulation [19-24], we present herein the first synthesis, biological evaluation and docking studies of enantiomerically pure AHL analogs with a hydroxyl group in position 2 of the acyl chain.

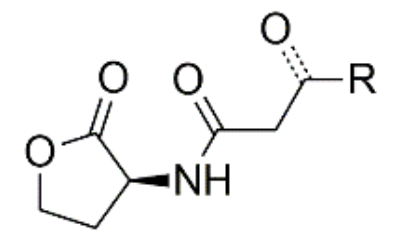

AHLs

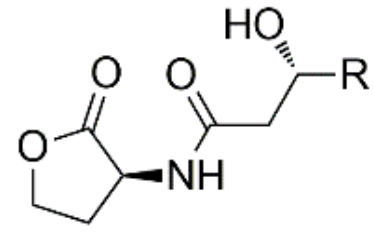

3-OH-AHLs

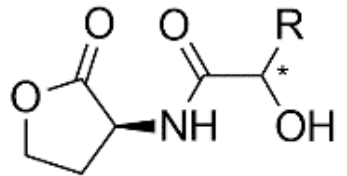

2-OH-AHLs (this study)

Fig. 1 Structure of AHLs as autoinducers in Gram negative bacteria.

\section{Results and discussion}

\section{Synthesis}

The synthesis of 2-hydroxy acylhomoserine lactones was achieved by coupling L-homoserine lactone and 2-hydroxy carboxylic acids using 1-(3-dimethylaminopropyl)-3-ethyl carbodiimide (EDC) as a coupling agent in the presence of 1-hydroxybenzotriazole (HOBt) [25]. Some 2hydroxy carboxylic acids were commercially available, such as $(R$ or $S)$-mandelic acid, $(R$ or $S)$ 2-hydroxy-4-phenylbutyric acid and ( \pm )-2-hydroxy-octanoic acid. The ( \pm )-2-hydroxy hexanoic or 
dodecanoic acids, were prepared from pentanoic and undecanoic acids by reaction with 2 equivalents of diethyl phosphorocyanidate (scheme 1) [26]. In this reaction, the intermediate dicyanophosphate is isolated then submitted to acidic hydrolysis under reflux which provokes subsequent decarboxylation providing the corresponding racemic $\alpha$-hydroxy carboxylic acid.

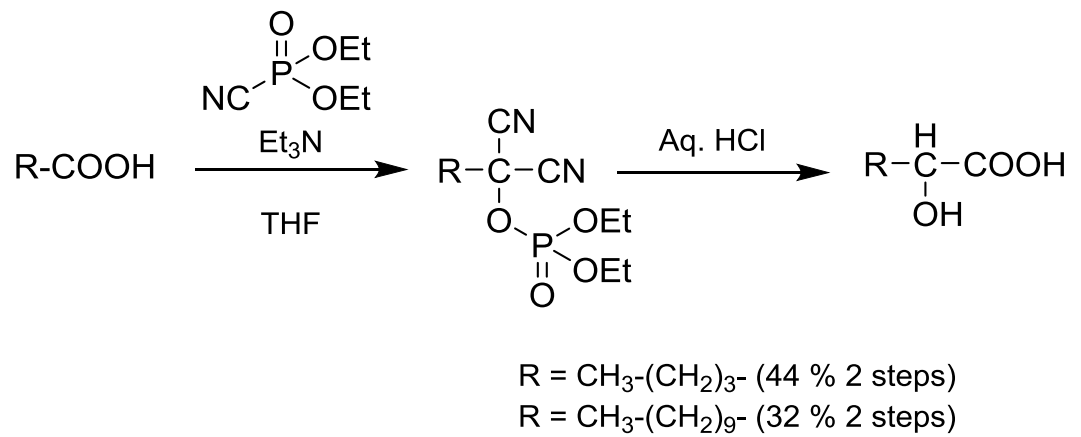

Scheme 1. Synthesis of ( \pm )-2-hydroxy hexanoic or dodecanoic acids.

The coupling reaction to obtain 2-hydroxy acylhomoserine lactones (scheme 2) uses the classical HOBt and EDC reagents starting from pure L-homoserine lactone. For 2-hydroxyacids available under their pure enantiomeric form, such as $(R$ or $S)$-mandelic acid and $(R$ or $S)$-2-hydroxy-4phenylbutyric acid, the reaction provides directly each single $2-\mathrm{OH}$ epimer as a single isomer. For 2-hydroxyacids available under their racemic mixture, such as ( \pm )-2-hydroxy-hexanoic, octanoic and -dodecanoic acids, the reaction with L-homoserine lactone gives two diastereoisomers. Pure $2(R)$ and 2(S)-hydroxy-L-homoserine lactones diastereoisomers were finally obtained after silica gel chromatography purification. 

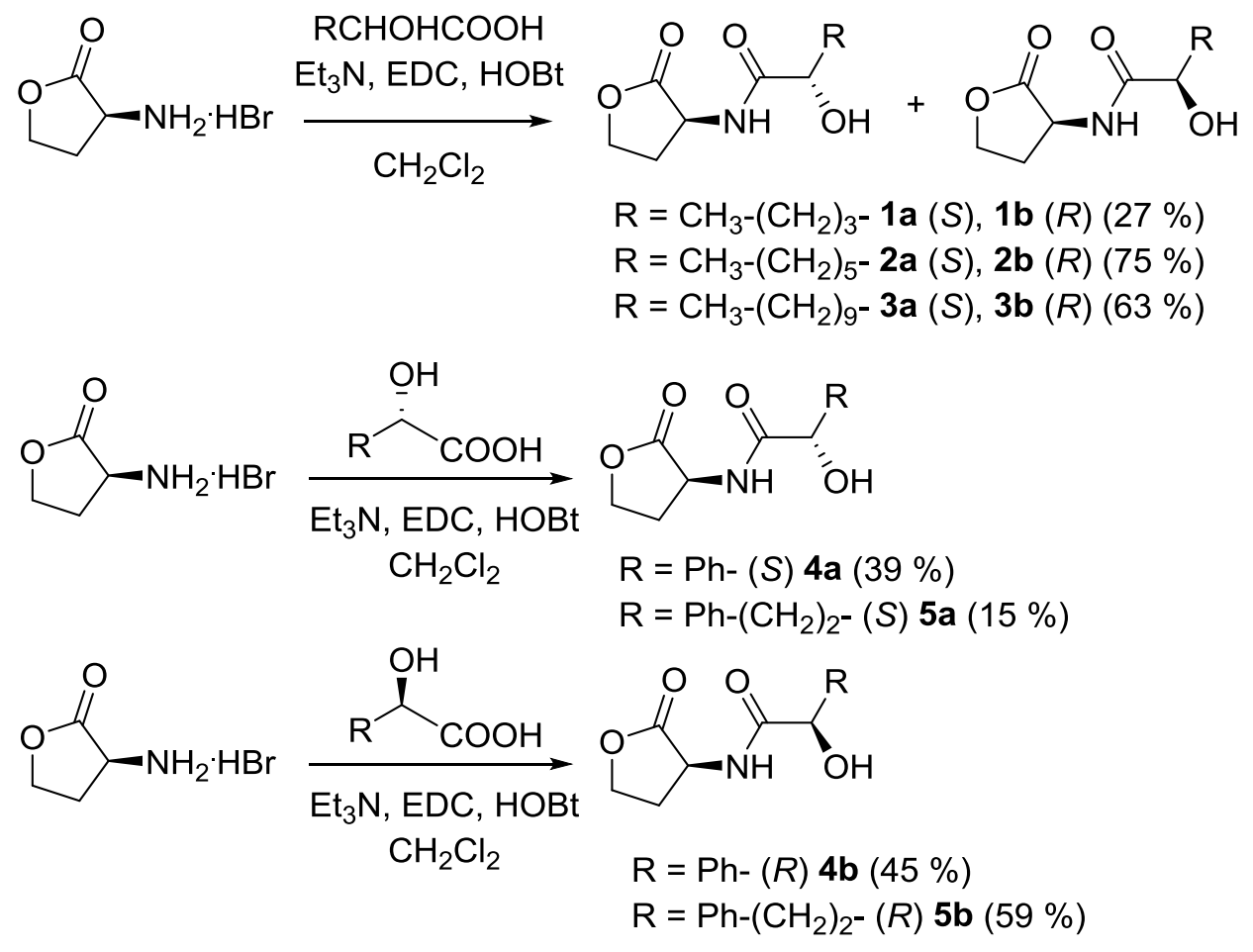

Scheme 2 Synthesis of 2-hydroxy acylhomoserine-L-lactones.

The absolute configuration at C-2 was assigned first for the 2-hydroxyoctanoyl AHL $\mathbf{2 a}$ as $S$ by X-ray diffraction (XRD) analysis (Fig. 2). The structure indeed shows clearly the $\alpha$-hydroxy amide functional group with the $S$ configuration at C-2.

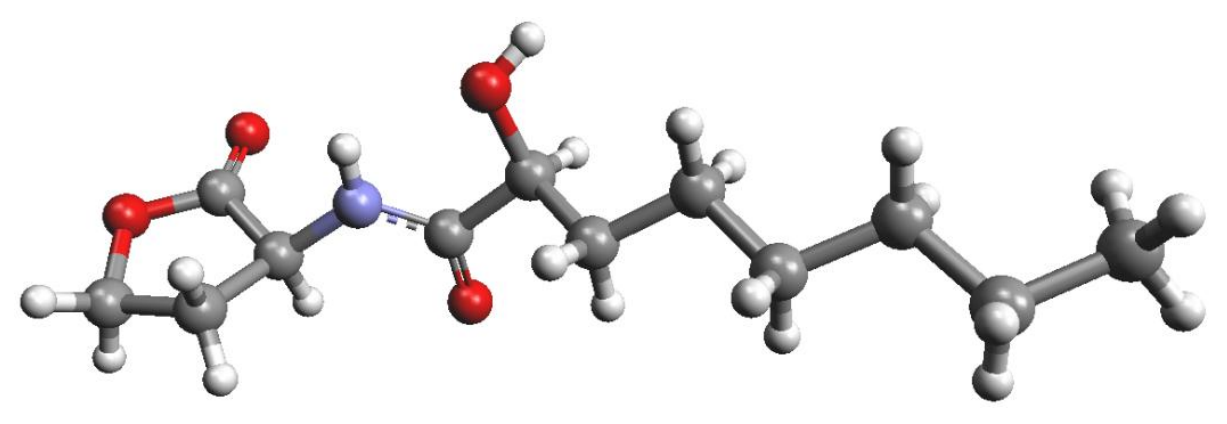

Fig. 2 Tridimensional structure of diastereoisomer 2a obtained from XRD. 
Then, we could assign the $R / S$ configuration at $\mathrm{C}-2$ in the series $\mathbf{1 - 3}$ by unambiguous comparison of ${ }^{1} \mathrm{H}$ NMR data (see ESI). Having in hands pure $\mathbf{2 a}$ and $\mathbf{2} \mathbf{b}$, distinctive chemical shifts for each diastereoisomer were found, notably $\mathrm{CHNH}$ at $\delta 4.74 \mathrm{ppm}$ for the $S$ isomer $2 \mathbf{a}$ and $\delta 4.55 \mathrm{ppm}$ for the $R$ isomer $\mathbf{2} \mathbf{b}$. The same patterns were clearly observed also in both isomers of $\mathbf{1 a b}$ and 3ab, respectively, allowing to assign the $S$ configuration to $\mathbf{1 a}$ and $\mathbf{3 a}$, and the $R$ one to $\mathbf{1 b}$ and 3b. Fully consistent differences for the $\mathrm{CHOH}$ of signals of both diastereosisomers were also found in the series 1-3.

\section{Biological evaluation}

All compounds were evaluated for their agonistic and antagonistic activity. For these experiments, the Escherichia coli strain NM522 equipped with the sensor plasmid pSB401 was used to monitor the bioluminescence induced by increasing concentrations of an AHL analog (agonistic activity). For the antagonistic activity, the bioluminescence was induced by $200 \mathrm{nM}$ of 3-oxo-hexanoyl-L-homoserine lactone (OHHL) and the residual bioluminescence was measured for increasing concentrations of AHL analogs [27]. The results are given in Table 1.

\begin{tabular}{lcc}
\hline Compounds & $\mathrm{IC}_{50}(\mu \mathrm{M})$ & $\mathrm{EC}_{50}(\mu \mathrm{M})$ \\
\hline $2 S$-OH-HHL (1a) & $>100$ & $15 \pm 6$ \\
$2 R$-OH-HHL (1b) & $11 \pm 3$ & $a$ \\
$2 S$-OH-OHL (2a) & $>100$ & $16 \pm 3$
\end{tabular}




\begin{tabular}{|c|c|}
\hline $2 R-\mathrm{OH}-\mathrm{OHL}(\mathbf{2 b})$ & $4 \pm 3$ \\
\hline $2 S-\mathrm{OH}-\mathrm{dDHL}(\mathbf{3 a})$ & $72 \pm 9$ \\
\hline $2 R-\mathrm{OH}-\mathrm{dDHL}(\mathbf{3 b})$ & $64 \pm 3$ \\
\hline 2S-OH-PAHL (4a) & $>100$ \\
\hline $2 R-\mathrm{OH}-\mathrm{PAHL}(\mathbf{4 b})$ & $84 \pm 4$ \\
\hline 2S-OH-PBHL (5a) & $17 \pm 2$ \\
\hline $2 R-\mathrm{OH}-\mathrm{PBHL}(\mathbf{5} \mathbf{b})$ & $15 \pm 6$ \\
\hline
\end{tabular}

Table $1 \mathrm{IC}_{50}$ and $\mathrm{EC}_{50}$ values for compounds 3-5. ${ }^{\mathrm{a}}$ Too week activity for accurate and meaningful $\mathrm{EC}_{50}$ measurement

An obvious difference in the properties between short chain compounds ( $\mathbf{1}$ and $\mathbf{2}$ ), and longer chain ones (compounds 3-5) is observed. For the short hexanoyl and octanoyl hydroxyl-AHLs 1a, $\mathbf{1 b}$ and $\mathbf{2 a}, \mathbf{2 b}$, the two isomers in each pair exert an opposite biological activity according to the configuration of the carbon atom $\mathrm{C}$-2 bearing the hydroxyl functional group. 2-Hydroxy hexanoyl-1-homoserine 1a (2-OH-HHL) and 2-hydroxy octanoyl-1-homoserine 2a (2-OH-OHL), both with an $S$ configuration at C-2, were found to be strong agonists with an $\mathrm{EC}_{50}$ value of $15 \pm$ 6 and $16 \pm 3 \mu \mathrm{M}$, respectively. In contrast, the other diastereoisomers $\mathbf{1 b}$ and $\mathbf{2 b}$ (with an $R$ configuration at C-2) were found to be extremely weaker agonist as illustrated in fig. 3. However, these latter were found to be highly potent antagonist with $\mathrm{IC}_{50}$ value of $11 \pm 3$ and $4 \pm 3 \mu \mathrm{M}$ respectively. 

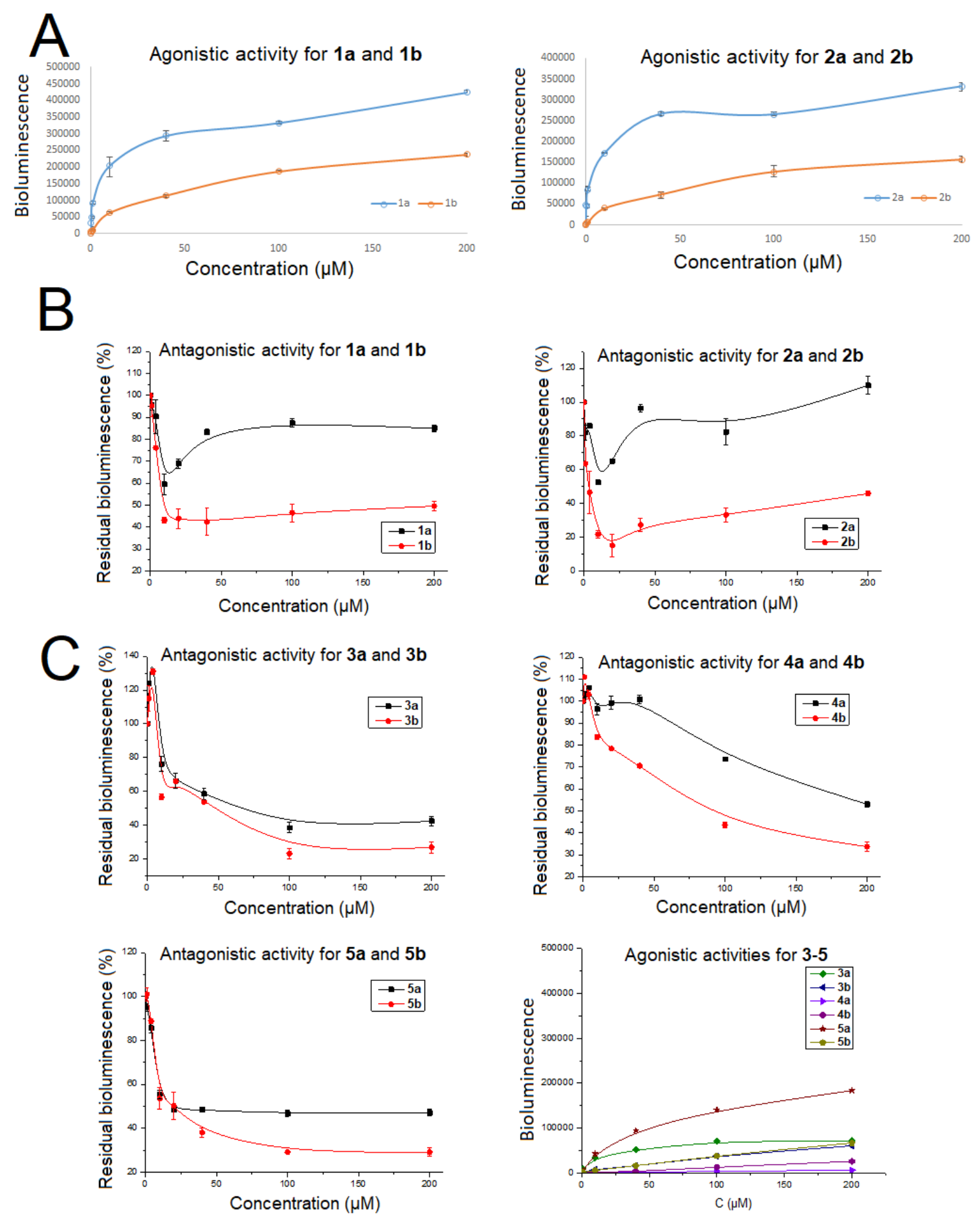

Fig. 3 Agonistic (A) and antagonistic (B) activities for compounds $\mathbf{1 a}, \mathbf{1 b}$ and $\mathbf{2 a}, \mathbf{2 b}$. (C) Agonistic and antagonistic activities for compounds 3-5. 
For analogs with longer chains, both diastereoisomers of compounds 3-5 were found to exert antagonistic activity with $\mathrm{IC}_{50}$ values ranging from $15 \mu \mathrm{M}$ to $84 \mu \mathrm{M}$ whatever their configuration

at C-2 (Table 1). Actually, only compounds 5ab exert significant activity, with antagonistic activity close to that of the hexanoyl analog $\mathbf{1 b}$, but not as potently as octanoyl compounds $\mathbf{2 b}$. Very weak agonistic activity was also observed however with levels preventing to get meaningful and accurate $\mathrm{EC}_{50}$ values (Fig. 3).

No effect of the configuration at C-2 was observed for these analogs which are less structurally close to the natural ligand of LuxR OHHL. Their effect on QS is therefore governed by the presence of hydrophobic side chains, with or without aromatic moieties, consistently with the reported effect of chain length for 3-oxo AHL and non-oxo analogs with long alkyl chain displaying antagonist activity in contrast with shorter chain [15].

\section{Docking studies}

The structural difference in the series of 2-hydroxy-AHL analogs was then investigated through docking studies using the LuxR model $[21,28]$ by comparing their binding mode to that of the natural ligand OHHL. This latter, depicted in fig. 4 [21], shows several hydrogen bonds (Table 2) between the $\mathrm{C}=\mathrm{O}$ of the lactone and Trp66, the $\mathrm{NH}$ of the amide functional group and Asp79, between the $\mathrm{C}=\mathrm{O}$ of the amide functional group and Tyr62 and also between the 3-oxo and a water molecule. The amide functional group is located in a polar area between Asp79 and Tyr62 whereas the alkyl chain is located in the hydrophobic pocket. 


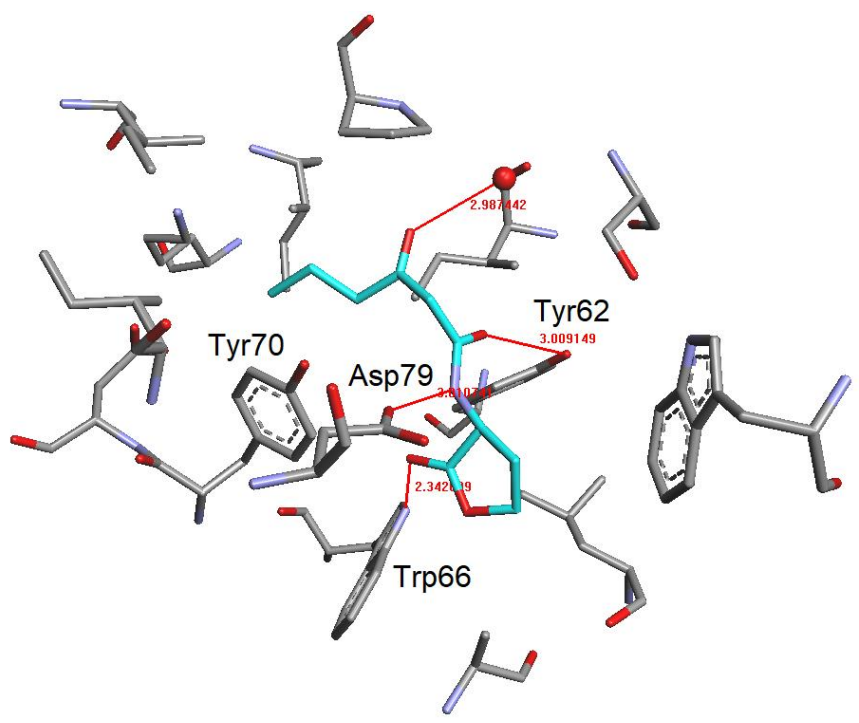

Fig. 4 Binding mode of the natural ligand within the binding site of the LuxR model (hydrogen bonds are represented with red lines).

All 2-OH AHL analogs of this study were docked within the binding site of LuxR and the docking results show a consistent hydrogen-bond networks in the series 1a-5a (configuration $S$ at $\mathrm{C}-2$ ) and in the series $\mathbf{1 b}-\mathbf{5 b}$ (configuration $R$ at C-2) (Table 2 and ESI). For the $S$ series 1a-5a, the hydrogen bond network is comparable to that of OHHL, notably exhibiting a hydrogen bond between the 2-OH and the water molecule imprisoned within the binding site. In the $R$ series $\mathbf{1 b}$ 5b, two new hydrogen bonds involve the 2-OH group and Tyr70 and Asp79 respectively. 


\begin{tabular}{|c|c|c|c|c|c|}
\hline \multirow[b]{2}{*}{ Compounds } & \multicolumn{4}{|c|}{ Hydrogen bonds network } & \multirow{2}{*}{$\begin{array}{c}\text { Interactions in the hydrophobic pocket } \\
\text { Side chain }\end{array}$} \\
\hline & $\begin{array}{l}\mathrm{C}=\mathrm{O} \\
\text { lactone }\end{array}$ & $\begin{array}{c}\mathrm{NH} \\
\text { amide }\end{array}$ & $\begin{array}{c}\mathrm{C}=\mathrm{O} \\
\text { amide }\end{array}$ & $2-\mathrm{OH}$ & \\
\hline $\begin{array}{l}\text { 1a (strong } \\
\text { agonist) }\end{array}$ & Trp66 & Asp79 & Tyr62 & $\mathrm{H}_{2} \mathrm{O}$ & Weak \\
\hline $\begin{array}{c}\mathbf{1 b} \text { (strong } \\
\text { antagonist) }\end{array}$ & Trp66 & Asp79 & Tyr62 & $\begin{array}{l}\text { Asp79 } \\
\text { Trp70 }\end{array}$ & Weak \\
\hline $\begin{array}{l}\text { 2a (strong } \\
\text { agonist) }\end{array}$ & Trp66 & Asp79 & Tyr62 & $\mathrm{H}_{2} \mathrm{O}$ & Weak \\
\hline $\begin{array}{c}\mathbf{2 b} \text { (strong } \\
\text { antagonist) }\end{array}$ & Trp66 & Asp79 & Tyr62 & $\begin{array}{l}\text { Asp79 } \\
\text { Trp70 }\end{array}$ & Weak \\
\hline $\begin{array}{c}\mathbf{3 a} \\
\text { (antagonist) }\end{array}$ & Trp66 & Asp79 & Tyr62 & $\mathrm{H}_{2} \mathrm{O}$ & Strong \\
\hline $\begin{array}{c}\mathbf{3 b} \\
\text { (antagonist) }\end{array}$ & Trp66 & Asp79 & Tyr62 & $\begin{array}{l}\text { Asp79 } \\
\text { Trp70 }\end{array}$ & Strong \\
\hline $\begin{array}{c}\mathbf{4 a} \\
\text { (antagonist) }\end{array}$ & Trp66 & Asp79 & Tyr62 & $\mathrm{H}_{2} \mathrm{O}$ & Strong + aromatic \\
\hline $\begin{array}{c}\mathbf{4 b} \\
\text { (antagonist) }\end{array}$ & Trp66 & Asp79 & Tyr62 & $\begin{array}{l}\text { Asp79 } \\
\text { Trp70 }\end{array}$ & Strong + aromatic \\
\hline $\begin{array}{c}\mathbf{5 a} \\
\text { (antagonist) }\end{array}$ & Trp66 & Asp79 & Tyr62 & $\mathrm{H}_{2} \mathrm{O}$ & Strong + aromatic \\
\hline $\begin{array}{c}\mathbf{5 b} \\
\text { (antagonist) }\end{array}$ & Trp66 & Asp79 & Tyr62 & $\begin{array}{l}\text { Asp79 } \\
\text { Trp70 }\end{array}$ & Strong + aromatic \\
\hline
\end{tabular}

Table 2 Hydrogen bonds network in the series 1-5 and interactions in the hydrophobic pocket.

The binding mode of both isomers $(S)-2-\mathrm{OH}-\mathrm{HHL}(\mathbf{1 a})$ and $(R)-2-\mathrm{OH}-\mathrm{HHL}(\mathbf{1 b})$ are depicted in Fig $5 \mathrm{~A}$ and $5 \mathrm{~B}$ respectively, together with a superimposition with the natural ligand OHHL for easy comparison. It is seen that the $(S)$-isomer binds the key residues of the binding site in a very close way as compared to the natural ligand, with the same hydrogen bonds network, and, importantly showing the hydroxyl group being involved in a hydrogen bond with the water molecule like the 3-oxo function does in OHHL. Binding exactly like the natural ligand, it is therefore anticipated to act as an agonist, consistently with the observed biological activity. In contrast, the $(R)$-isomer gave a completely different result, with the hydroxyl group being 
involved in new hydrogen bonds with Tyr70 and Asp79, two important residues strictly conserved in the LuxR family [28]. These new interactions can be therefore suggested to be responsible for the antagonistic activity of the $R$ isomer in this series of short chain analogs. Identical observations were made in the case of the octanoyl compounds $\mathbf{2 a}$ and $\mathbf{2 b}$.

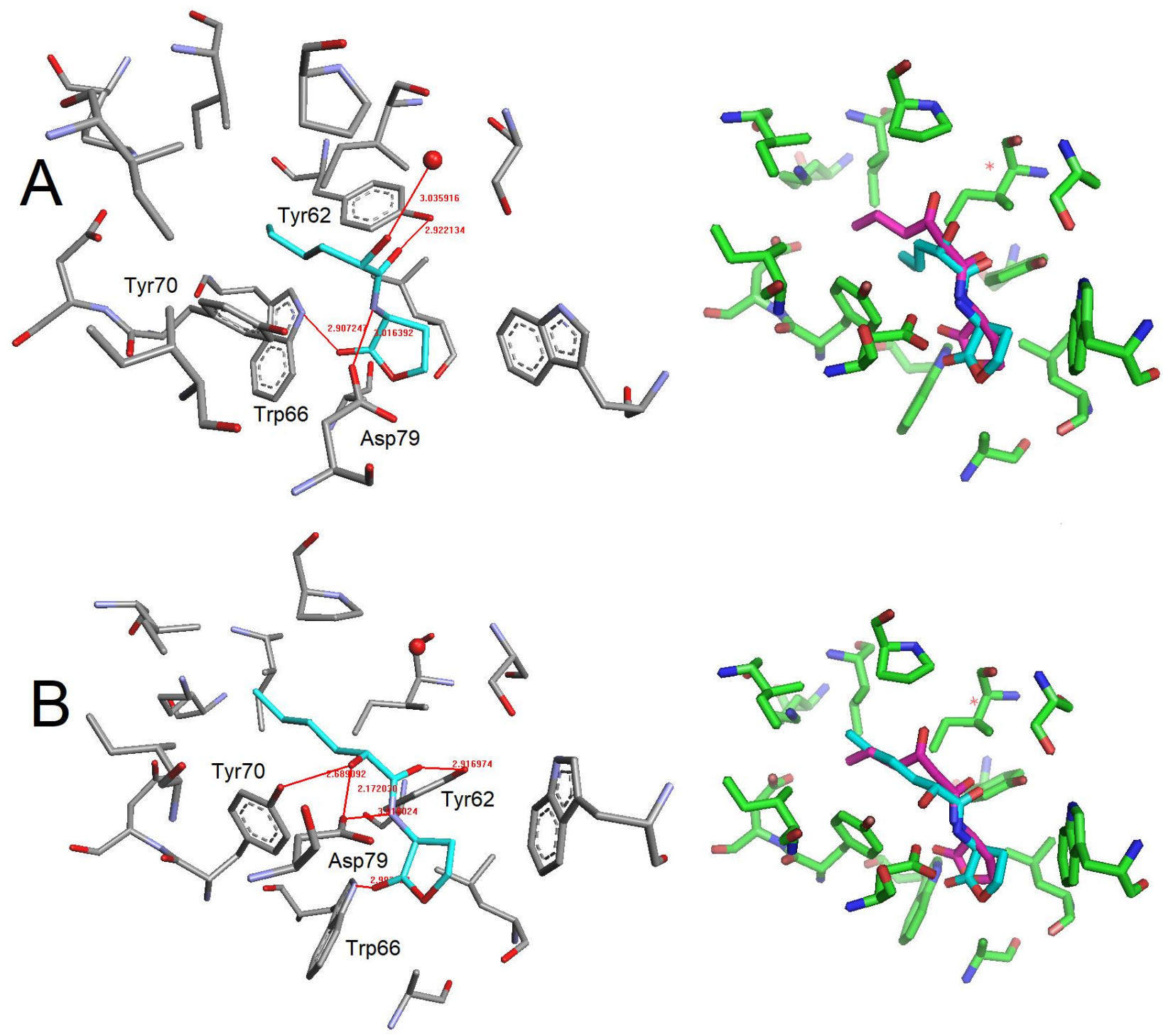

Fig. 5 Docking results of the diastereoisomers $(S)-2-\mathrm{OH}-\mathrm{HHL}(\mathbf{A}),(R)-2-\mathrm{OH}-\mathrm{HHL}(\mathbf{B})$ within the binding site of the LuxR model (left). Superimposition (right) of (S)-2-OH-HHL, $(R)-2-\mathrm{OH}-\mathrm{HHL}$ (in cyan) with the natural ligand OHHL (in magenta) within the binding site of the LuxR model. 
For the longer chain compounds $\mathbf{3 a}$ and $\mathbf{3 b}$, the long alkyl chain interacts deeply in the hydrophobic pocket for both isomers (Table 2). For aromatic compounds 4-5, attractive interactions are observed resulting from their aromaticity and the presence of aromatic residues in the binding site, namely Tyr62 and Tyr70 (Table 2). These interactions are observed whatever the configuration at C-2. It is therefore observed that, as soon as hydrophobic interactions exist, these interactions become pre-eminent in orienting the activity towards an antagonistic activity whatever the configuration at $\mathrm{C}-2$, whereas when weaker, the effect of the configuration becomes critical in orienting towards either agonistic or antagonistic activity.

\section{Conclusions}

In summary, we have unveiled that 2-hydroxy AHL analogs are Vibrio fischeri-quorum sensing modulators. This systematic study includes enantiomerically and diastereoisomerically pure analogs with different alkyl chains as well as aromatic compounds. Several clear trends can be established is this series, with respect to the influence of the configuration at $\mathrm{C}-2$, and to the structure of the side chains.

The very potent $2-\mathrm{OH}-\mathrm{HHL}$ and $2-\mathrm{OH}-\mathrm{OHL}$ with short alkyl chain display either agonistic or antagonistic activity according to the configuration of the carbon atom with the hydroxyl functional group. For analogs with long alkyl chain or aromatic analogs, they exert antagonistic whatever the configuration at C-2. Flexible docking experiments performed with all compounds showed that the $(2 R)-\mathrm{OH}$ configuration induces new hydrogen bonds with Tyr70 and Asp79, two importantly conserved residues in the LuxR protein family, while the $(2 S)-\mathrm{OH}$ configuration 
exhibits a binding mode comparable to the natural ligand 3-oxo-hexanoyl-L-homoserine lactone (OHHL). For the 2-OH-HHL and 2-OH-OHL (short alkyl chain), these key interactions are proposed to govern the agonistic ( $S$ configuration) or antagonistic ( $R$ configuration). For the analogs with long alkyl chain $\mathbf{3 a}$ and $\mathbf{3 b}$ and aromatic analogs, strong hydrophobic interactions or attractive interactions are responsible of the antagonistic activity whatever the configuration at C2.

\section{Experimental section}

\section{Synthesis}

L-homoserine lactone hydrobromide was synthesized as previously reported [29].

General procedure for the synthesis of 2-hydroxy carboxylic acid (route A):

To a solution of undecanoic acid or pentanoic acid $(2.0 \mathrm{mmol})$ and diethyl phosphorocyanidate (DEPC) $(90 \%, 4.2 \mathrm{mmol})$ in THF $(4 \mathrm{~mL})$ was added triethylamine $(2.1 \mathrm{mmol})$ at $-20^{\circ} \mathrm{C}$. The reaction mixture was stirred for $3 \mathrm{~h}$ at $-20^{\circ} \mathrm{C}$. The mixture was diluted with ether or EtOAc (30 $\mathrm{mL})$ and washed with water $(2 \times 20 \mathrm{~mL})$, the organic phase was collected, dried over anhydrous $\mathrm{Na}_{2} \mathrm{SO}_{4}$, concentrated and purified by flash chromatography to get the intermediate product dicyanophosphate. A mixture of dicyanophosphate $(0.7 \mathrm{mmol})$ and $\mathrm{HCl}(37 \%, 2.9 \mathrm{~mL})$ was heated at reflux for $12 \mathrm{~h}$. The reaction mixture was cooled, then extracted with ether $(3 \times 20 \mathrm{~mL})$, and the organic phase was dried over anhydrous $\mathrm{Na}_{2} \mathrm{SO}_{4}$, concentrated and purified by flash chromatography to get the desired product 2-hydroxy acid.

General procedure for the synthesis of 2-hydroxy acylhomoserine lactones (route B): 
To a solution of 2-hydroxy acid $(0.5 \mathrm{mmol})$ and $\mathrm{L}$ - $\alpha$-amino- $\gamma$-butyrolactone hydrobromide $(0.6$ mmol) in $\mathrm{CH}_{2} \mathrm{Cl}_{2}(4 \mathrm{~mL})$ were added triethylamine (1.1 mmol) and 1-(3-dimethylaminopropyl)-3ethyl carbodiimide hydrochloride $(\mathrm{EDC})(0.55 \mathrm{mmol})$ and 1-hydroxybenzotriazole $(\mathrm{HOBt})(0.5$ $\mathrm{mmol})$ at $0^{\circ} \mathrm{C}$. The reaction mixture was stirred for $1 \mathrm{~h}$ at $0^{\circ} \mathrm{C}$ and overnight at room temperature. The solvent was evaporated and EtOAc $(20 \mathrm{~mL})$ was added. The mixture was washed respectively with brine, $1 \% \mathrm{HCl}, 5 \% \mathrm{NaHCO}_{3}$, and brine, dried over anhydrous $\mathrm{Na}_{2} \mathrm{SO}_{4}$, concentrated and purified by flash chromatography to get the desired product.

(S)-2-hydroxy- $N$-((S)-2-oxotetrahydrofuran-3-yl)hexanamide (1a) (2-OH-HHL). From pentanoic acid following the general procedure for route A. Flash chromatography of the crude product (2:1 EtOAc-pentane) afforded 2-hydroxyhexanoic acid (44 \% for two steps) as a white solid. ${ }^{1} \mathrm{H}$ NMR data were consistent with the literature [30]. According to the general procedure for route B, flash chromatography of the crude product (3:1 EtOAc-pentane) afforded 1a and $\mathbf{1 b}$ $(27 \%)$ as a white solid. ${ }^{1} \mathrm{H}$ NMR (300 MHz, Chloroform- $d$ ) $\delta 7.38(\mathrm{~d}, J=7.9 \mathrm{~Hz}, 1 \mathrm{H}, \mathrm{NH}), 4.77$ (dt, $J=11.7,8.4 \mathrm{~Hz}, 1 \mathrm{H}, \mathrm{CH}-\mathrm{NH}), 4.46$ (td, $J=9.1,1.3 \mathrm{~Hz}, 1 \mathrm{H}, \mathrm{OCH}$-lactone), 4.29 (ddd, $J=$ 11.2, 9.2, 6.0 Hz, 1H, OCHH-lactone), 4.17 (dt, $J=8.3,4.1 \mathrm{~Hz}, 1 \mathrm{H}, \mathrm{CH}-\mathrm{OH}), 3.75$ (d, $J=4.8$ $\mathrm{Hz}, 1 \mathrm{H}, \mathrm{OH}), 2.69$ (m, 1H, CHH-lactone), $2.34-2.14$ (m, 1H, CHH-lactone), 1.81 (m, 1H, CH$\mathrm{CH}), 1.60(\mathrm{~m}, 1 \mathrm{H}, \mathrm{CH}-\mathrm{CH} \mathrm{H}), 1.45-1.26\left(\mathrm{~m}, 4 \mathrm{H}, 2 \times \mathrm{CH}_{2}\right), 0.84\left(\mathrm{t}, J=7.1 \mathrm{~Hz}, 3 \mathrm{H}, \mathrm{CH}_{3}\right) .{ }^{13} \mathrm{C}$ NMR (75 MHz, Chloroform- $d$ ) $\delta 175.9(\mathrm{CO}), 175.5(\mathrm{CO}), 72.2(\mathrm{CHOH}), 66.0\left(\mathrm{OCH}_{2}\right.$-lactone), $48.2(\mathrm{CH}-\mathrm{NH}), 34.1\left(\mathrm{CHCH}_{2}\right), 29.7\left(\mathrm{CH}_{2}\right.$-lactone $), 27.2\left(\mathrm{CH}_{2}\right), 22.4\left(\mathrm{CH}_{2}\right), 14.0\left(\mathrm{CH}_{3}\right)$. ESI$\operatorname{HRMS}(\mathrm{M}+\mathrm{Na})^{+}:$238.1050; found: $238.1052 .[\alpha] 24 \mathrm{D}=-60(\mathrm{c}=0.5$, acetone).

(R)-2-hydroxy- $N$-((S)-2-oxotetrahydrofuran-3-yl)hexanamide (1b) (2-OH-HHL). ${ }^{1} \mathrm{H}$ NMR (300 MHz, Chloroform- $d$ ) $\delta 7.24(\mathrm{~d}, J=7.5 \mathrm{~Hz}, 1 \mathrm{H}, \mathrm{NH}), 4.55$ (ddd, $J=11.1,8.7,6.9 \mathrm{~Hz}, 1 \mathrm{H}$, CH-NH), 4.49 (td, $J=9.0,1.5 \mathrm{~Hz}, 1 \mathrm{H}$, OCHH-lactone), 4.29 (ddd, $J=10.9,9.2,6.2 \mathrm{~Hz}, 1 \mathrm{H}$, 
OCHH-lactone), 4.14 (dt, $J=8.1,4.1 \mathrm{~Hz}, 1 \mathrm{H}, \mathrm{CH}-\mathrm{OH}), 3.12(\mathrm{~s}, 1 \mathrm{H}, \mathrm{OH}), 2.84-2.63$ (m, 1H, CHH-lactone), 2.27 (m, 1H, CHH-lactone), $1.84(\mathrm{~m}, 1 \mathrm{H}, \mathrm{CH}-\mathrm{CH} \mathrm{H}), 1.65(\mathrm{~m}, 1 \mathrm{H}, \mathrm{CH}-\mathrm{CH} \mathrm{H})$, $1.48-1.23\left(\mathrm{~m}, 4 \mathrm{H}, 2 \times \mathrm{CH}_{2}\right), 0.91\left(\mathrm{t}, J=7.1 \mathrm{~Hz}, 3 \mathrm{H}, \mathrm{CH}_{3}\right) .{ }^{13} \mathrm{C} \mathrm{NMR}(75 \mathrm{MHz}$, Chloroform- $d) \delta$ $175.4(\mathrm{CO}), 174.9(\mathrm{CO}), 72.2(\mathrm{CHOH}), 66.1\left(\mathrm{OCH}_{2}\right.$-lactone $), 48.8(\mathrm{CH}-\mathrm{NH}), 34.2\left(\mathrm{CHCH}_{2}\right)$, $29.6\left(\mathrm{CH}_{2}\right.$-lactone), $27.1\left(\mathrm{CH}_{2}\right), 22.4\left(\mathrm{CH}_{2}\right), 13.9\left(\mathrm{CH}_{3}\right) . \mathrm{HRMS}(\mathrm{M}+\mathrm{Na})^{+}$: 238.1050; found: $238.1047[\alpha] 24 \mathrm{D}=+9.6(\mathrm{c}=0.415$, acetone $)$.

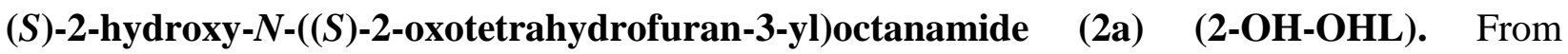
commercial available 2-hydroxyoctanoic acid following the general procedure for route B, flash chromatography of the crude product (3:1 EtOAc-pentane) afforded $\mathbf{2 a}$ and $\mathbf{2 b}(75 \%)$ as a white solid. ${ }^{1} \mathrm{H}$ NMR (500 MHz, Chloroform-d) $\delta 7.25$ (d, $\left.J=6.0 \mathrm{~Hz}, 1 \mathrm{H}, \mathrm{NH}\right), 4.74$ (ddd, $J=11.8$, 8.7, 7.5 Hz, 1H, CH-NH), 4.47 (td, $J=9.0,1.2 \mathrm{~Hz}, 1 \mathrm{H}$, OCHH-lactone), 4.30 (ddd, $J=11.2,9.3$, $6.0 \mathrm{~Hz}, 1 \mathrm{H}$, OCHH-lactone), 4.18 (ddd, J = 8.5, 5.0, $3.7 \mathrm{~Hz}, 1 \mathrm{H}, \mathrm{CH}-\mathrm{OH}), 3.32$ (d, J = 5.0 Hz, 1H, OH), 2.74 (m, 1H, CHH-lactone), 2.22 (m, 1H, CHH-lactone), 1.83 (m, 1H, CH-CHH), 1.62 $(\mathrm{m}, 1 \mathrm{H}, \mathrm{CH}-\mathrm{CHH}), 1.41\left(\mathrm{p}, J=7.1,6.6 \mathrm{~Hz}, 2 \mathrm{H}, \mathrm{CH}_{2}\right), 1.36-1.20\left(\mathrm{~m}, 6 \mathrm{H}, 3 \times \mathrm{CH}_{2}\right), 0.87(\mathrm{t}, J=$ $\left.7.0 \mathrm{~Hz}, 3 \mathrm{H}, \mathrm{CH}_{3}\right) .{ }^{13} \mathrm{C} \mathrm{NMR}(126 \mathrm{MHz}$, Chloroform-d) $\delta 175.6(\mathrm{CO}), 175.2(\mathrm{CO}), 72.3(\mathrm{CHOH})$, $66.0\left(\mathrm{OCH}_{2}\right.$-lactone $), 48.3(\mathrm{CH}-\mathrm{NH}), 34.5\left(\mathrm{CHCH}_{2}\right), 31.7\left(\mathrm{CH}_{2}\right), 29.9\left(\mathrm{CH}_{2}\right.$-lactone $), 29.0$ $\left(\mathrm{CH}_{2}\right), 25.0\left(\mathrm{CH}_{2}\right), 22.9\left(\mathrm{CH}_{2}\right), 14.1\left(\mathrm{CH}_{3}\right)$. ESI-HRMS(M+Na) $)^{+}$: 266.1363; found: 266.1364. $[\alpha] 24 \mathrm{D}=-47.3(\mathrm{c}=0.55$, acetone $)$.

(R)-2-hydroxy- $N$-((S)-2-oxotetrahydrofuran-3-yl)octanamide (2b) (2-OH-OHL). ${ }^{1} \mathrm{H}$ NMR (500 MHz, Chloroform- $d$ ) $\delta 7.24(\mathrm{~d}, J=6.4 \mathrm{~Hz}, 1 \mathrm{H}, \mathrm{NH}), 4.55(\mathrm{ddd}, J=11.3,8.8,6.9 \mathrm{~Hz}, 1 \mathrm{H}$, CH-NH), 4.49 (td, $J=9.1,1.4 \mathrm{~Hz}, 1 \mathrm{H}, \mathrm{OCH}$-lactone), 4.29 (ddd, $J=10.6,9.2,6.1 \mathrm{~Hz}, 1 \mathrm{H}$, OCHH-lactone), 4.14 (ddd, $J=8.7,5.3,3.8 \mathrm{~Hz}, 1 \mathrm{H}, \mathrm{CH}-\mathrm{OH}), 3.11(\mathrm{~d}, J=5.0 \mathrm{~Hz}, 1 \mathrm{H}, \mathrm{OH}), 2.73$ (m, 1H, CHH-lactone), 2.27 (m, 1H, CHH-lactone), 1.85 (m, 1H, CH-CHH), 1.65 (m, 1H, CH- 
$\mathrm{CHH}), 1.42\left(\mathrm{~m}, 2 \mathrm{H}, \mathrm{CH}_{2}\right), 1.36-1.22\left(\mathrm{~m}, 6 \mathrm{H}, 3 \times \mathrm{CH}_{2}\right), 0.87\left(\mathrm{t}, J=6.7 \mathrm{~Hz}, 3 \mathrm{H}, \mathrm{CH}_{3}\right) .{ }^{13} \mathrm{C} \mathrm{NMR}$ (126 MHz, Chloroform-d) $\delta 175.4(\mathrm{CO}), 174.9(\mathrm{CO}), 72.2(\mathrm{CHOH}), 66.1\left(\mathrm{OCH}_{2}\right.$-lactone), 48.8 (CH-NH), $34.5\left(\mathrm{CHCH}_{2}\right), 31.7\left(\mathrm{CH}_{2}\right), 29.6\left(\mathrm{CH}_{2}\right.$-lactone), $29.0\left(\mathrm{CH}_{2}\right), 24.9\left(\mathrm{CH}_{2}\right), 22.6\left(\mathrm{CH}_{2}\right)$, $14.1\left(\mathrm{CH}_{3}\right)$. ESI-HRMS $(\mathrm{M}+\mathrm{Na})^{+}:$266.1363; found: 266.1361. $[\alpha] 24 \mathrm{D}=+6.2(\mathrm{c}=0.325$, acetone).

(S)-2-hydroxy- $N$-((S)-2-oxotetrahydrofuran-3-yl)dodecanamide (3a) (2S-OH-dDHL) : From undecanoic acid following the general procedure for route A. Flash chromatography of the crude product (1:1 EtOAc-pentane) afforded 2-hydroxydodecanoic acid (32\% for two steps) as a white solid. ${ }^{1} \mathrm{H}$ NMR data were consistent with the literature [30]. According to the general procedure for route $\mathrm{B}$, flash chromatography of the crude product (1:2 EtOAc-pentane) afforded $\mathbf{3 a}$ and $\mathbf{3 b}$ $(63 \%)$ as a white solid. ${ }^{1} \mathrm{H}$ NMR (400 MHz, Chloroform- $\left.d\right) \delta 7.30(\mathrm{~d}, J=7.6 \mathrm{~Hz}, 1 \mathrm{H}, \mathrm{NH}), 4.75$ (dt, $J=11.7,8.2 \mathrm{~Hz}, 1 \mathrm{H}, \mathrm{CH}-\mathrm{NH}), 4.47$ (td, $J=9.0,1.2 \mathrm{~Hz}, 1 \mathrm{H}$, OCHH-lactone), 4.29 (ddd, $J=$ 11.2, 9.2, $5.9 \mathrm{~Hz}, 1 \mathrm{H}, \mathrm{OCH}$-lactone), 4.17 (dd, $J=8.2,3.7 \mathrm{~Hz}, 1 \mathrm{H}, \mathrm{CH}-\mathrm{OH}), 3.24$ (br, 1H, OH), 2.72 (m, 1H, CHH-lactone), 2.22 (m, 1H, CHH-lactone), 1.81 (m, 1H, CH-CHH), 1.61 (m, 1H, CH-CHH), $1.46-1.20\left(\mathrm{~m}, 16 \mathrm{H}, 8 \times \mathrm{CH}_{2}\right), 0.87\left(\mathrm{t}, J=8.0 \mathrm{~Hz}, 3 \mathrm{H}, \mathrm{CH}_{3}\right) .{ }^{13} \mathrm{C} \mathrm{NMR}(101$ $\mathrm{MHz}$, Chloroform- $d) \delta 175.7(\mathrm{CO}), 175.3(\mathrm{CO}), 72.3(\mathrm{CHOH}), 66.0\left(\mathrm{OCH}_{2}\right.$-lactone), $48.3(\mathrm{CH}-$ NH), $34.5\left(\mathrm{CHCH}_{2}\right), 31.9\left(\mathrm{CH}_{2}\right), 29.8\left(\mathrm{CH}_{2}\right), 29.6\left(\mathrm{CH}_{2}\right), 29.5\left(2 \times \mathrm{CH}_{2}\right), 29.4\left(\mathrm{CH}_{2}\right), 29.3\left(\mathrm{CH}_{2}\right)$, $25.1\left(\mathrm{CH}_{2}\right), 22.7\left(\mathrm{CH}_{2}\right), 14.1\left(\mathrm{CH}_{3}\right)$. ESI-HRMS(M+Na) ${ }^{+}: 322.1989$; found: 322.1976. [ $\alpha$ ]24 D = $-36(\mathrm{c}=0.39$, acetone $)$.

(R)-2-hydroxy- $N$-((S)-2-oxotetrahydrofuran-3-yl)dodecanamide (3b) (2R-OH-dDHL): ${ }^{1} \mathrm{H}$ NMR (400 MHz, Chloroform- $d$ ) $\delta 7.21(\mathrm{~d}, J=6.9 \mathrm{~Hz}, 1 \mathrm{H}, \mathrm{NH}), 4.55$ (ddd, $J=11.4,8.8,6.9 \mathrm{~Hz}$, 1H, CH-NH), 4.49 (td, $J=9.1,1.5 \mathrm{~Hz}, 1 \mathrm{H}, \mathrm{OCHH}-$ lactone), 4.29 (ddd, $J=11.0,9.3,6.2 \mathrm{~Hz}, 1 \mathrm{H}$, OCHH-lactone), 4.14 (dd, $J=8.2,3.8 \mathrm{~Hz}, 1 \mathrm{H}, \mathrm{CH}-\mathrm{OH}), 3.04$ (br, 1H, OH), 2.74 (m, 1H, CHH- 
lactone), 2.26 (m, 1H, CHH-lactone), 1.85 (m, 1H, CH-CHH), 1.64 (m, 1H, CH-CHH), 1.47 $1.20\left(\mathrm{~m}, 16 \mathrm{H}, 8 \times \mathrm{CH}_{2}\right), 0.87\left(\mathrm{t}, J=8.0 \mathrm{~Hz}, 3 \mathrm{H}, \mathrm{CH}_{3}\right) .{ }^{13} \mathrm{C}$ NMR $(101 \mathrm{MHz}$, Chloroform- $d) \delta$ $175.4(\mathrm{CO}), 174.9(\mathrm{CO}), 72.3(\mathrm{CHOH}), 66.1\left(\mathrm{OCH}_{2}\right.$-lactone $), 48.8(\mathrm{CH}-\mathrm{NH}), 34.5\left(\mathrm{CHCH}_{2}\right)$, $31.9\left(\mathrm{CH}_{2}\right), 29.6\left(\mathrm{CH}_{2}\right), 29.6\left(2 \times \mathrm{CH}_{2}\right), 29.5\left(\mathrm{CH}_{2}\right), 29.3\left(2 \times \mathrm{CH}_{2}\right), 25.0\left(\mathrm{CH}_{2}\right), 22.7\left(\mathrm{CH}_{2}\right), 14.1$ $\left(\mathrm{CH}_{3}\right)$. ESI-HRMS $(\mathrm{M}+\mathrm{Na})^{+}:$322.1989; found: 322.1985. [ $\left.\alpha\right] 24 \mathrm{D}=0$ (c=0.62, acetone).

(S)-2-hydroxy- $N$-((S)-2-oxotetrahydrofuran-3-yl)-2-phenylacetamide (4a) (2S-OH-PAHL). From commercial available (S)-2-hydroxy-2-phenylacetic acid following the general procedure for route B, flash chromatography of the crude product (4:1 EtOAc-pentane) afforded 4a (39\%) as a white solid. ${ }^{1} \mathrm{H}$ NMR $\left(300 \mathrm{MHz}\right.$, Acetone- $\left.d_{6}\right) \delta 7.97(\mathrm{~d}, J=8.0 \mathrm{~Hz}, 1 \mathrm{H}, \mathrm{NH}), 7.59-7.44(\mathrm{~m}$, 2H, Ph), $7.42-7.19$ (m, 3H, Ph), $5.40(\mathrm{~d}, J=4.6 \mathrm{~Hz}, 1 \mathrm{H}, \mathrm{OH}), 5.12$ (d, $J=4.4 \mathrm{~Hz}, 1 \mathrm{H}, \mathrm{CH}-\mathrm{OH})$, 4.72 (ddd, $J=11.2,9.0,8.1 \mathrm{~Hz}, 1 \mathrm{H}, \mathrm{CH}-\mathrm{NH}), 4.40$ (td, $J=8.9,1.8 \mathrm{~Hz}, 1 \mathrm{H}$, OCHH-lactone), 4.29 (ddd, $J=10.7,8.9,6.3 \mathrm{~Hz}, 1 \mathrm{H}$, OCHH-lactone), $2.53(\mathrm{~m}, 1 \mathrm{H}, \mathrm{CH}$-lactone), 2.36 (m, 1H,

CHH-lactone). ${ }^{13} \mathrm{C}$ NMR (101 MHz, Acetone-d6) $\delta 174.7$ (CO), 172.3 (CO), $140.8(\mathrm{Ph}), 128.0$ (2C, $\mathrm{Ph}), 127.6(\mathrm{Ph}), 126.8(2 \mathrm{C}, \mathrm{Ph}), 73.9(\mathrm{CHOH}), 65.2\left(\mathrm{OCH}_{2}\right.$-lactone), $48.0(\mathrm{CH}-\mathrm{NH}), 28.7$ $\left(\mathrm{CH}_{2} \text {-lactone). ESI-HRMS(M+Na }\right)^{+}:$258.0737; found: 258.0735. [ $\left.\alpha\right] 24 \mathrm{D}=+14(\mathrm{c}=0.425$, acetone).

(R)-2-hydroxy- $N$-((S)-2-oxotetrahydrofuran-3-yl)-2-phenylacetamide (4b) (2R-OH-PAHL). From commercial available $(R)$-2-hydroxy-2-phenylacetic acid following the general procedure for route $\mathrm{B}$, flash chromatography of the crude product (4:1 EtOAc-pentane) afforded $\mathbf{4 b}$ (45 \%) as a white solid. ${ }^{1} \mathrm{H}$ NMR $(300 \mathrm{MHz}$, Acetone-d6) $\delta 8.06(\mathrm{~d}, J=8.2 \mathrm{~Hz}, 1 \mathrm{H}, \mathrm{NH}), 7.57-7.46$ (m, 2H, Ph), $7.43-7.29(\mathrm{~m}, 3 \mathrm{H}, \mathrm{Ph}), 5.43(\mathrm{~d}, \mathrm{~J}=4.5 \mathrm{~Hz}, 1 \mathrm{H}, \mathrm{OH}), 5.11(\mathrm{~d}, J=4.4 \mathrm{~Hz}, 1 \mathrm{H}, \mathrm{CH}-$ OH), $4.71(\mathrm{ddd}, J=11.1,9.1,8.2 \mathrm{~Hz}, 1 \mathrm{H}, \mathrm{CH}-\mathrm{NH}), 4.39(\mathrm{td}, J=8.9,1.9 \mathrm{~Hz}, 1 \mathrm{H}$, OCHHlactone), 4.28 (ddd, $J=10.6,8.9,6.4 \mathrm{~Hz}, 1 \mathrm{H}, \mathrm{OCH}$-lactone), 2.54 (m, 1H, CHH-lactone), 2.35 
(m, 1H, CHH-lactone). ${ }^{13} \mathrm{C}$ NMR (75 MHz, Acetone-d6) $\delta 174.7$ (CO), 172.4 (CO), 140.8 (Ph), $128.1(2 \mathrm{C}, \mathrm{Ph}), 127.7(\mathrm{Ph}), 127.0(2 \mathrm{C}, \mathrm{Ph}), 74.0(\mathrm{CHOH}), 65.2\left(\mathrm{OCH}_{2}\right.$-lactone $), 48.1(\mathrm{CH}-\mathrm{NH})$, $28.5\left(\mathrm{CH}_{2}\right.$-lactone). ESI-HRMS(M+Na) ${ }^{+}: 258.0737$; found: $258.0740 .[\alpha] 24 \mathrm{D}=-59(\mathrm{c}=0.61$, acetone).

(S)-2-hydroxy- $N$-((S)-2-oxotetrahydrofuran-3-yl)-4-phenylbutanamide (5a) (2S-OH-PBHL). From commercial available (S)-2-hydroxy-4-phenylbutanoic acid following the general procedure for route $\mathrm{B}$, flash chromatography of the crude product (5:1 EtOAc-pentane) afforded 5a $(15 \%)$ as a white solid. ${ }^{1} \mathrm{H}$ NMR $(300 \mathrm{MHz}$, Chloroform-d) $\delta 7.34$ (d, $J=7.9 \mathrm{~Hz}, 1 \mathrm{H}, \mathrm{NH})$, $7.31-7.27$ (m, 1H, Ph), $7.26-7.14(\mathrm{~m}, 4 \mathrm{H}, \mathrm{Ph}), 4.75$ (ddd, $J=11.8,8.8,7.9 \mathrm{~Hz}, 1 \mathrm{H}, \mathrm{CH}-\mathrm{NH})$, $4.46(\mathrm{td}, J=9.1,1.3 \mathrm{~Hz}, 1 \mathrm{H}$, OCHH-lactone), 4.28 (ddd, $J=11.2,9.3,6.0 \mathrm{~Hz}, 1 \mathrm{H}, \mathrm{OCH}-$ lactone), 4.18 (dt, $J=8.0,3.8 \mathrm{~Hz}, 1 \mathrm{H}, \mathrm{CH}-\mathrm{OH}), 3.72(\mathrm{~d}, J=4.3 \mathrm{~Hz}, 1 \mathrm{H}, \mathrm{OH}), 2.85-2.73(\mathrm{~m}$, 2H, $\left.\mathrm{CH}_{2}\right), 2.73-2.60$ (m, 1H, CHH-lactone), $2.31-2.08$ (m, 2H, CHH-lactone, $\mathrm{CHCH}$ ), 2.02 - $1.86(\mathrm{~m}, 1 \mathrm{H}, \mathrm{CHCHH}) .{ }^{13} \mathrm{C}$ NMR $(75 \mathrm{MHz}$, Chloroform- $d$ ) $\delta 175.8(\mathrm{CO}), 175.1$ (CO), 141.2 (Ph), 128.5 (2C, Ph), 128.5 (2C, Ph), $126.1(\mathrm{Ph}), 71.5(\mathrm{CHOH}), 66.0\left(\mathrm{OCH}_{2}\right.$-lactone), $48.3(\mathrm{CH}-$ $\mathrm{NH}), 36.0\left(\mathrm{CH}_{2}\right), 31.3\left(\mathrm{CH}_{2}\right), 29.7\left(\mathrm{CH}_{2} \text {-lactone). ESI-HRMS(M+Na) }\right)^{+}$: 286.1050; found: 286.1050. $[\alpha] 24 \mathrm{D}=-35$ (c=0.46, acetone).

(R)-2-hydroxy- $N$-((S)-2-oxotetrahydrofuran-3-yl)-4-phenylbutanamide

(5b) (2R-OH-

PBHL). From commercial available $(R)$-2-hydroxy-4-phenylbutanoic acid following the general procedure for route $\mathrm{B}$, flash chromatography of the crude product (5:1 EtOAc-pentane) afforded 5a $(59 \%)$ as a white solid. ${ }^{1} \mathrm{H}$ NMR $\left(300 \mathrm{MHz}\right.$, Acetone- $\left.d_{6}\right) \delta 7.85(\mathrm{~d}, J=8.1 \mathrm{~Hz}, 1 \mathrm{H}, \mathrm{NH}), 7.35$ $-7.08(\mathrm{~m}, 5 \mathrm{H}, \mathrm{Ph}), 4.88(\mathrm{~s}, 1 \mathrm{H}, \mathrm{OH}), 4.71(\mathrm{ddd}, J=11.2,9.0,8.2 \mathrm{~Hz}, 1 \mathrm{H}, \mathrm{CH}-\mathrm{NH}), 4.41(\mathrm{td}, J=$ 8.9, $1.8 \mathrm{~Hz}, 1 \mathrm{H}$, OCHH-lactone), 4.30 (ddd, $J=10.6,8.9,6.3 \mathrm{~Hz}, 1 \mathrm{H}$, OCHH-lactone), 4.10 (dd, $J=7.7,4.0 \mathrm{~Hz}, 1 \mathrm{H}, \mathrm{CH}-\mathrm{OH}), 2.83-2.70\left(\mathrm{~m}, 2 \mathrm{H}, \mathrm{CH}_{2}\right), 2.56(\mathrm{~m}, 1 \mathrm{H}, \mathrm{CH}$-lactone $), 2.48-2.32$ 
(m, 1H, CHH-lactone), $2.17-2.07(\mathrm{~m}, 1 \mathrm{H}, \mathrm{CHCHH}), 1.98-1.79(\mathrm{~m}, 1 \mathrm{H}, \mathrm{CHCHH}) .{ }^{13} \mathrm{C}$ NMR (75 MHz, Acetone-d6) $\delta 174.7$ (CO), 174.0 (CO), 142.1 (Ph), 128.4 (2C, Ph), $128.3(2 \mathrm{C}, \mathrm{Ph})$, $125.7(\mathrm{Ph}), 70.8(\mathrm{CHOH}), 65.2\left(\mathrm{OCH}_{2}\right.$-lactone $), 47.9(\mathrm{CH}-\mathrm{NH}), 36.7\left(\mathrm{CH}_{2}\right), 30.9\left(\mathrm{CH}_{2}\right), 28.6$ $\left(\mathrm{CH}_{2}\right.$-lactone). ESI-HRMS(M+Na) ${ }^{+}$: 286.1050; found: 286.1052. [ $\left.\alpha\right] 24 \mathrm{D}=-8.3(\mathrm{c}=0.48$, acetone).

\section{Biological evaluation}

Escherichia coli strain NM522 equipped with the sensor plasmid pSB401 was grown in Luria broth $(50 \mathrm{~mL})$ at $30^{\circ} \mathrm{C}$. After $18 \mathrm{~h}$, this bacterial culture was diluted 10 times and $100 \mu \mathrm{L}$ per well (96 wells plates) were added. For agonistic activity, compounds were tested at increasing concentrations in DMSO (max $2 \%$ in a total volume of $200 \mu \mathrm{L}$ of LB). For antagonistic activity, compounds were tested at increasing concentrations in DMSO (max $2 \%$ in a total volume of 200 $\mu \mathrm{L})$ in competition with OHHL $(200 \mathrm{nM})$. Bioluminescence was measured with a Tecan spark luminometer.

\section{Molecular modeling}

Compounds were drawn with Vega $\mathrm{ZZ}$ and 3D structures were generated and minimized using the SP4 force field (Gasteiger charges assignment) [31-33]. The LuxR model reported in previous study was employed for docking experiments. The docking box centered on the natural ligand $(15 \times 15 \times 15 \AA)$ was created by selecting residues of the binding site. Docking experiments were achieved using Arguslab [34] with the genetic algorithm engine [35] with default parameters.

\section{Acknowledgments}


The authors are grateful to CNRS, MESRI for financial support and to the China Scholarship Council for a scholarship to Qiang Zhang. The authors thank Sylvie Reverchon for helpful discussions.

\section{Conflicts of interest}

There are no conflict to declare.

\section{Notes and references}

[1] N.C. Reading, V. Sperandio, Quorum sensing: the many languages of bacteria, FEMS Microbiol. Lett. 254(1) (2006) 1-11.

[2] N. Garg, G. Manchanda, A. Kumar, Bacterial quorum sensing: circuits and applications, Antonie Van Leeuwenhoek 105(2) (2014) 289-305.

[3] B. LaSarre, M.J. Federle, Exploiting quorum sensing to confuse bacterial pathogens, Microbiol. Mol. Biol. Rev. 77(1) (2013) 73-111.

[4] K. Reuter, A. Steinbach, V. Helms, Interfering with Bacterial Quorum Sensing, Perspect. Medicin. Chem. 8 (2016) 1-15.

[5] S.B. Tay, W.S. Yew, Development of quorum-based anti-virulence therapeutics targeting Gram-negative bacterial pathogens, Int. J. Mol. Sci. 14(8) (2013) 16570-99.

[6] G. Brackman, T. Coenye, Quorum sensing inhibitors as anti-biofilm agents, Curr. Pharm. Des. 21(1) (2015) 5-11.

[7] G.D. Geske, J.C. O'Neill, H.E. Blackwell, Expanding dialogues: from natural autoinducers to non-natural analogues that modulate quorum sensing in Gram-negative bacteria, Chem. Soc. Rev. 37(7) (2008) 1432-47. 
[8] A.M. Stevens, Y. Queneau, L. Soulère, S. von Bodman, A. Doutheau, Mechanisms and synthetic modulators of AHL-dependent gene regulation, Chem. Rev. 111(1) (2011) 4-27.

[9] W.R. Galloway, J.T. Hodgkinson, S.D. Bowden, M. Welch, D.R. Spring, Quorum sensing in Gram-negative bacteria: small-molecule modulation of AHL and AI-2 quorum sensing pathways, Chem. Rev. 111(1) (2011) 28-67.

[10] K. Papenfort, B.L. Bassler, Quorum sensing signal-response systems in Gram-negative bacteria, Nat. Rev. Microbiol. 14(9) (2016) 576-88.

[11] K.Y. Le, M. Otto, Quorum-sensing regulation in staphylococci-an overview, Front. Microbiol. 6 (2015) 1174.

[12] C.S. Pereira, J.A. Thompson, K.B. Xavier, AI-2-mediated signalling in bacteria, FEMS Microbiol. Rev. 37(2) (2013) 156-81.

[13] X. Ke, L.C. Miller, B.L. Bassler, Determinants governing ligand specificity of the Vibrio harveyi LuxN quorum-sensing receptor, Mol. Microbiol. 95(1) (2015) 127-42.

[14] R.G. Zhang, K.M. Pappas, J.L. Brace, P.C. Miller, T. Oulmassov, J.M. Molyneaux, J.C. Anderson, J.K. Bashkin, S.C. Winans, A. Joachimiak, Structure of a bacterial quorumsensing transcription factor complexed with pheromone and DNA, Nature 417(6892) (2002) 971-4.

[15] A.L. Schaefer, B.L. Hanzelka, A. Eberhard, E.P. Greenberg, Quorum sensing in Vibrio fischeri: probing autoinducer-LuxR interactions with autoinducer analogs, J. Bacteriol. 178(10) (1996) 2897-901.

[16] A. Eberhard, C.A. Widrig, P. McBath, J.B. Schineller, Analogs of the autoinducer of bioluminescence in Vibrio fischeri, Arch. Microbiol. 146(1) (1986) 35-40. 
[17] D.M. Stacy, M.A. Welsh, P.N. Rather, H.E. Blackwell, Attenuation of quorum sensing in the pathogen Acinetobacter baumannii using non-native N-Acyl homoserine lactones, ACS Chem. Biol. 7(10) (2012) 1719-28.

[18] J.G. Cao, Z.Y. Wei, E.A. Meighen, The lux autoinducer-receptor interaction in Vibrio harveyi: binding parameters and structural requirements for the autoinducer, Biochem. J. 312 (1995) 439-44.

[19] M. Frezza, S. Castang, J. Estephane, L. Soulere, C. Deshayes, B. Chantegrel, W. Nasser, Y. Queneau, S. Reverchon, A. Doutheau, Synthesis and biological evaluation of homoserine lactone derived ureas as antagonists of bacterial quorum sensing, Bioorg. Med. Chem. 14(14) (2006) 4781-91.

[20] M. Frezza, L. Soulere, S. Reverchon, N. Guiliani, C. Jerez, Y. Queneau, A. Doutheau, Synthetic homoserine lactone-derived sulfonylureas as inhibitors of Vibrio fischeri quorum sensing regulator, Bioorg. Med. Chem. 16(7) (2008) 3550-6.

[21] J. Estephane, J. Dauvergne, L. Soulere, S. Reverchon, Y. Queneau, A. Doutheau, N-Acyl-3amino-5H-furanone derivatives as new inhibitors of LuxR-dependent quorum sensing: Synthesis, biological evaluation and binding mode study, Bioorg. Med. Chem. Lett. 18(15) (2008) 4321-4.

[22] M. Boukraa, M. Sabbah, L. Soulere, M.L. El Efrit, Y. Queneau, A. Doutheau, AHLdependent quorum sensing inhibition: synthesis and biological evaluation of alpha-(Nalkyl-carboxamide)-gamma-butyrolactones and alpha-(N-alkyl-sulfonamide)-gammabutyrolactones, Bioorg. Med. Chem. Lett. 21(22) (2011) 6876-9.

[23] M. Sabbah, M. Bernollin, A. Doutheau, L. Soulere, Y. Queneau, A new route towards fimbrolide analogues: importance of the exomethylene motif in LuxR dependent quorum sensing inhibition, MedChemComm 4(2) (2013) 363-366. 
[24] S. Li, J. Wawrzyniak, Y. Queneau, L. Soulère, 2-Substituted Aniline as a Simple Scaffold for LuxR-Regulated QS Modulation, Molecules 22(12) (2017).

[25] V.D. Mouchlis, V. Magrioti, E. Barbayianni, N. Cermak, R.C. Oslund, T.M. Mavromoustakos, M.H. Gelb, G. Kokotos, Inhibition of secreted phospholipases $\mathrm{A}_{2}$ by 2oxoamides based on $\alpha$-amino acids: Synthesis, in vitro evaluation and molecular docking calculations, Bioorg. Med. Chem. 19(2) (2011) 735-43.

[26] M. Mizuno, T. Shioiri, Reaction of carboxylic acids with diethyl phosphorocyanidate; A novel synthesis of homologated alpha-hydroxycarboxylic acids from carboxylic acids, Tetrahedron Lett. 39(50) (1998) 9209-9210.

[27] S. Reverchon, B. Chantegrel, C. Deshayes, A. Doutheau, N. Cotte-Pattat, New synthetic analogues of $\mathrm{N}$-acyl homoserine lactones as agonists or antagonists of transcriptional regulators involved in bacterial quorum sensing, Bioorg. Med. Chem. Lett. 12(8) (2002) $1153-7$.

[28] L. Soulere, M. Frezza, Y. Queneau, A. Doutheau, Exploring the active site of acyl homoserine lactones-dependent transcriptional regulators with bacterial quorum sensing modulators using molecular mechanics and docking studies, J. Mol. Graph. Model. 26(2) (2007) 581-590.

[29] T. Persson, T.H. Hansen, T.B. Rasmussen, M.E. Skinders $\varnothing$, M. Givskov, J. Nielsen, Rational design and synthesis of new quorum-sensing inhibitors derived from acylated homoserine lactones and natural products from garlic, Org. Biomol. Chem. 3(2) (2005) 253-62.

[30] K. Orito, Y. Seki, H. Suginome, T. Iwadare, Synthesis of S-methyl 2-hydroxyalkanethioates, 2-hydroxyalkanoic acids and related-compounds via the addition-reaction of tris(methylthio)methanide ion to alkanals, Bull. Chem. Soc. Jpn. 62(6) (1989) 2013-2017. 
[31] A. Pedretti, L. Villa, G. Vistoli, VEGA: a versatile program to convert, handle and visualize molecular structure on Windows-based PCs, J. Mol. Graph. Model. 21(1) (2002) 47-9.

[32] A. Pedretti, L. Villa, G. Vistoli, VEGA--an open platform to develop chemo-bio-informatics applications, using plug-in architecture and script programming, J. Comput. Aided Mol. Des. 18(3) (2004) 167-73.

[33] L. Soulere, Y. Queneau, Conformational and docking studies of acyl homoserine lactones as a robust method to investigate bioactive conformations, Comput. Biol. Chem. 79 (2019) 4854.

[34] M.A. Thompson, ArgusLaB 4.0.1, Seattle, WA planetaria Software LLC (2004).

[35] G.M. Morris, D.S. Goodsell, R.S. Halliday, R. Huey, W.E. Hart, R.K. Belew, A.J. Olson, Automated Docking Using a Lamarckian Genetic Algorithm and an Empirical Binding Free Energy Function, J. Comput. Chem. 19(14) (1998) 1639-1662. 